\title{
PENGARUH KEPUASAN KERJA TERHADAP KOMITMEN ORGANISASI DAN TURNOVER INTENTION (STUDI PADA LOSARI HOTEL SUNSET BALI)
}

\author{
Ni Luh Sili Antari \\ Sekolah Tinggi Ilmu Ekonomi Triatma Mulya \\ e-mail : siliantari@gmail.com
}

\begin{abstract}
Abstrak
Penelitian ini bertujuan untuk mengetahui pengaruh kepuasan kerja terhadap komitmen organisasi dan turnover intention pada Losari Hotel Sunset Bali. Penelitian ini merupakan penelitian sensus, dimana seluruh populasi digunakan sebagai sampel yaitu sebanyak 50 orang. Teknik analisis dalam penelitian ini menggunakan teknik analisis jalur atau parth analysis, yang sebelumnya dilakukan pengujian instrumen dan uji asumsi klasik yang diolah dengan program SPSS 17.0 for windows. Hasil analisis penunjukkan bahwa 1) kepuasan kerja berpengaruh positif terhadap komitmen organisasi; 2) kepuasan kerja berpengaruh negatif terhadap turnover intentions; dan 3) komitmen organisasi berpengaruh negatif terhadap turniver intentions karyawan pada Losari Hotel Sunset Bali. Saran dalam penelitian ini adalah pihak manajemen diharapkan lebih memperhatikan kepuasan kerja, komitmen organisasi untuk menurunkan turnover intentions. Pihak menajemen perlu melakukan meningkatkan kepuasan gaji sesuai dengan beban kerja, meningkatkan komitmen afektif yang menanamkan persepsi karyawan bahwa meninggalkan perusahaan akan menimbulkan biaya dan resiko yang tinggi dan meningkatkan kesejahteraan karyawan lebih dari perusahaan lainnya untuk menurunkan turnover karyawan.
\end{abstract}

Kata kunci: Kepusan Kerja, Komitmen, Turnover Intention

\begin{abstract}
This study aimed at determining the effect of job satisfaction on organizational commitment and turnover intention in Losari Hotel Sunset Bali. This study was a census study, in which the entire population was used as a sample about 50 respondents. Analytical techniques in this study using path analysis techniques, instrument testing was done previously and classical assumption test processed by SPSS 17.0 program for windows program. The results of the analysis showed that 1) job satisfaction had a positive effect on organizational commitment; 2) job satisfaction had a negative effect on turnover intentions; and 3) organizational commitment negatively affect employee turnover intentions inLosari Hotel Sunset Bali. Suggestions given in this study to the management is expected to pay more attention to job satisfaction, organizational commitment to reduce turnover intentions. Management needs to increase salary satisfaction in accordance with workload, increase affective commitment which instills employee perception that leaving the company will incur high costs and risks and improve employee welfare more than other companies to lower employee turnover.
\end{abstract}

Keywords: Job Satisfaction, Commitment, Turnover Intention 


\section{Pendahuluan}

Bali adalah salah satu provinsi yang memiliki kebudayaan yang sangat unik dan menarik, yang mengantarkan Bali sebagai daerah tujuan pariwisata dunia. Berbagai fasilitas pendukung disektor pariwisata terus berkembang pesat di Bali, salah satunya di bidang perhotelan. Agar mampu bersaing pada bidang yang sejenis, pihak manajemen harus memiliki keunggulan disegala bidang, terutama keunggulan pada sumber daya manusianya. Sumber daya manusia merupakan aset yang sangat penting, karena manusia merupakan sumber daya yang dinamis dan selalu dibutuhkan dalam tiap proses produksi barang maupun jasa, oleh karena itu pengelolaan sumber daya mencakup penyediaan tenaga kerja yang bermutu, mempertahankan kualitas dan mengendalikan biaya ketenagakerjaan harus mendapatkan perhatian yang serius bagi pihak manajemen.

Perkembangan konsep manajemen sumber daya manusia telah mengarah pada tuntutan untuk lebih memperhatikan kebijakan yang diterapkan organisasi terhadap karyawan. Kebijakan yang tidak sesuai dengan kebutuhan dan harapan pekerja akan membawa dampak buruk pada sikap kerja karyawan yang secara tidak langsung akan menimbulkan adanya turnover karyawan.Turnover karyawan merupakan perpindahan pekerja dalam pasar kerja, baik antar perusahaan, pekerjaan, dan antar status sebagai karyawan tetap maupun tidak tetap. Terjadinya turnover merupakan suatu hal yang tidak dikehendaki oleh semua organisasi, khususnya Losari Hotel Sunset Bali karena lebih banyak dampak yang merugikan organisasi dibanding dampak yang menguntungkan.

Losari Hotel Sunset Bali adalah hotel ke 8 dari 9 hotel Losari di Indonesia yang tersebar di kota-kota seperti Makassar, Jakarta dan Bali. Losari Sunset Hotel Bali mempunyai 59 kamar yang terdiri dari 4 Kamar Standar, 48 Kamar Superior dan 7 Kamar Deluxe. Berdasarkan data yang diperoleh menunjukkan bahwa adanya peningkatan turnover karyawan dari tahunketahun. Pada tahun 2014 tingkat turnover karyawan sebesar 6,67 persen dan ditahun 2016 meningkat menjadi 15,7 persen. Angka tersebut menunjukkan bahwa tingkat turnover di Losari Hotel Sunset Bali Tahun 2014 sampai 2016 tergolong tinggi. Menurut Gillis (1994) (dalam Setiawan 2013) turnover karyawan dikatakan normal berkisar antara 5 persen - 10 persen pertahun, dan tergolong tinggi apabila lebih dari 10 persen pertahun. Berdasarkan hasil wawancara dengan beberapa karyawan hal yang menyebabkan tingginya tingkat turnover disebabkan dikarenakan adanya ketidak puas dengan komitmen organisasi. Pihak perusahaan, dinilai kurang memberikan apresiasi terhadap karyawan seperti kurangnya pemberian insentif dan bonus bagi karyawan. Karyawan yang tidak puas mengakibatkan komitmennya akan rendah sehingga kemungkinan akan keluar dari organisasi.

Penelitian yang dilakukan Koh dan Boo (2004) menemukan bahwa terdapat hubungan positif yang signifikan antara kepuasan kerja dan komitmen organisasi. Semakin tinggi kepuasan kerja yang dirasakan oleh karyawan, semakin tinggi pula komitmen organisasional mereka. Lebih lanjut Azeem, (2010) mengemukakan bahwa supervisi, gaji, kepuasan kerja, umur, dan job tenure merupakan beberapa prediktor dari komitmen organisasional yang signifikan.

\section{Metode}

Penelitian ini dilakukan di Losari Hotel Sunset Bali. Populasi dalam penelitian ini adalah seluruh karyawan tetap yang bekerja pada Losari Hotel Sunset Bali yaitu sebanyak 50 orang. Arikunto (2002) menyatakan "Bahwa apabila subyek kurang dari 100 lebih baik diambil semua, sehingga penelitian merupakan penelitian populasi. Selanjutnya jika subyek lebih besar dari 100 dapat diambil antara $10-15 \%$ atau $20-25 \%$ atau lebih". Berdasarkan hal tersebut maka penelitian ini mengambil seluruh sampel yaitu sebanyak 50 orang yang merupakan penelitian sensus.

Adapun definisi operasional dalam penelitian adalah sebagai berikut:

1. Kepuasan Kerja (X1)

Merupakan sikap karyawan Losari Hotel Sunset Bali terhadap aspek-aspek pekerjaannya yang dapat menimbulkan perasaan menyenangkan atau tidak menyenangkan. 
Indikator pengukuran kepuasan kerja dalam penelitian ini adalah kepuasan gaji, kesempatan promosi karir, kepuasan terhadap supervisi, kepuasan terhadap hubungan personal dan kepuasan terhadap pekerjaan itu sendiri.

\section{Komitmen Organisasi (Y1)}

Merupakan sebuah keadaan psikologi yang kuat antara karyawan Losari Hotel Sunset Bali dengan tujuan dan nilai organisasi yang dapat mempengaruhi apakah karyawan akan tetap bertahan dalam organisasi atau tidak. Indikator komitmen organisasi dalam penelitian ini adalah komitmen afektif, komitmen kontinyu, dan komitmen normatif.

3. Turnover Intentions (Y2)

Merupakan keinginan karyawan Losari Hotel Sunset Bali untuk keluar dari perusahaan. Indikator turnover intention dalam penelitian ini adalah kecenderungan meninggalkan organisasi, kemungkinan mencari pekerjaan lain, kemungkinan meninggalkan organisasi dalam waktu dekat dan adanya alternatif pekerjaan yang lebih baik.

Penelitian ini menggunakan analisis jalur atau "path analysis". Sebelum dianalisis lebih lanjut, dilakukan pengujian instrumen (uji validitas dan uji reliabilitas) dan uji asumsi klasik yaitu uji normalitas, multikolinearitas, dan heteroskedastisitas, yang nantinya diolah dengan program SPSS 17.0 for windows. Langkah-langkah dalam pengujian analisis jalur dilakukan dengan melakukan beberapa tahapan sebagai berikut: pengembangan diagram jalur, konversi diagram jalur ke dalam persamaan, uji asumsi dan validitas model, dan interpretasi hasil penelitian.

\section{Hasil Dan Pembahasan Karakteristis Responden}

Data dalam penelitian ini diperoleh melalui kuisioner yang disebarkan kepada 50 orang responden yang merupakan karyawan Losari Sunset Hotel Bali. Berdasarkan data mengenai identitas karyawan Losari Sunset Hotel Bali, karyawan tergolong karyawan yang sangat produktif untuk melaksanakan tugas dan pekerjaan dengan baik. Hal ini didasarkan dari tingkat usia karyawan yang didominasi usia 20 sampai 29 tahun. Jenis kelamin pria lebih banyak bekerja pada Losari Sunset Hotel Bali dengan persentase 68 persen atau 34 orang, hal ini menggambarkan bahwa tingginya minat pria/laki-laki bekerja pada Losari Sunset Hotel Bali. Karyawan lebih banyak memiliki masa kerja kurang dari 5 tahun, hal ini dikarenakan tingginya angka turnover intentions yang menyebabkan karyawan Losari Sunset Hotel Bali lebih banyak memiliki masa kerja yang tergolong baru. Dilihat dari status perkawinan, karyawan Losari Sunset Hotel Bali didominasi oleh karyawan yang berstatus belum kawin dengan tingkat pendidikan lebih banyak SMU/SMK yaitu sebesar 62,0 persen. Informasi ini memberi gambaran pentingnya pendidikan dan latihan bagi karyawan untuk peningkatan kemampuan dan wawasan dalam melaksanakan tugas yang diberikan.

\section{Hasil Uji Validitas dan Reliabelitas}

Berdasarkan rekapitulasi hasil perhitungan nilai korelasi product moment dari tiap-tiap item pertanyaan diperoleh hasil lebih besar dari 0,3. Hal ini berarti semua butir pertanyaan dalam kuesioner dapat dikatakan valid. Hasil uji reliabilitas menunjukkan bahwa nilai crombach's alfa if item lebih besar dari 0,6, artinya bahwa semua variabel dalam kuesioner tersebut dapat dikatakan reliabel.

\section{Hasil Uji Asumsi Klasik}

Berdasarkan hasil uji normalitas menunjukkan nilai sig Kolmogorov-Smirnov variabel kepuasan kerja sebesar 0,177, komitmen organisasi sebesar 0,442 dan turnover intention sebesar 0,392, maka dapat disimpulkan semua variabel penelitian mempunyai angka signifikansi lebih dari 0,050 berarti data terdistribusi normal.

Hasil pengujian multikolinearitas menunjukkan bahwa tidak adanya gejala multikolinearitas karena nilai VIF pada variabel kepuasan kerja $(2,466)$, dan komitmen organisasi $(2,466)$ lebih kecil dari 10 , sehingga dapat disimpulkan bahwa antar variabel bebas tidak terjadi persoalan multikolinearitas.

Hasil uji heterokedastisitas menunjukkan pada gambar scatterplot diagram tidak ditemukan adanya pola tertentu, seperti titik-titik yang membentuk suatu pola tertentu yang 
teratur (bergelombang, melebar kemudian menyempit), di mana pada Gambar 6.1 di atas, terlihat titik-titik menyebar secara acak, tidak membentuk suatu pola tertentu yang jelas, serta tersebar baik di atas maupun di bawah angka 0 pada sumbu Y. Hal ini berarti tidak terjadi heteroskedastisitas pada model regresi dalam penelitian ini.

Gambar 4.1

Uji Heterokedastisitas

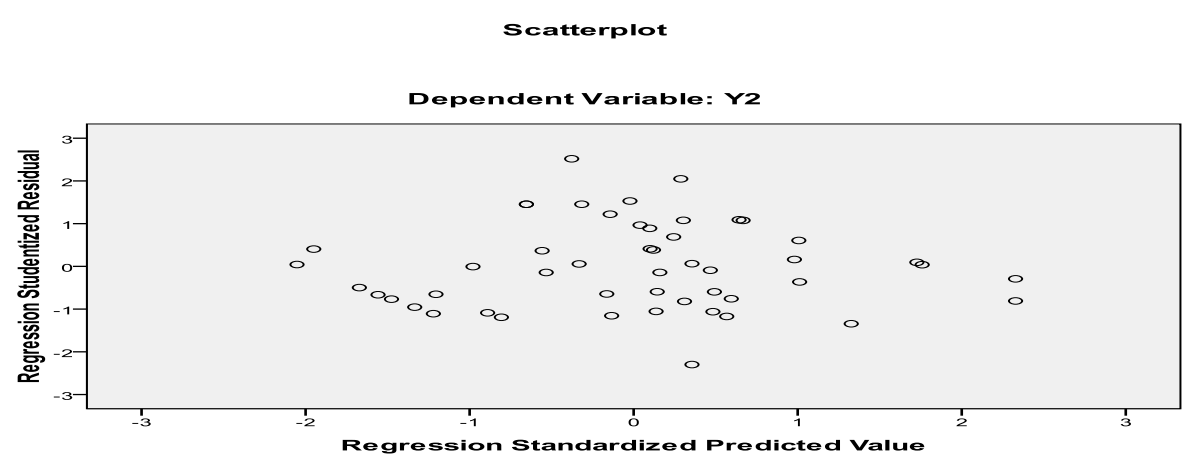

\section{Hasil Analisis Parth}

Berdasarkan hasil uji kesesuaian model diperoleh hasil koefisien determinasi sebesar 0,859 , hal ini berarti bahwa sebesar 85,9 persen turnover intentions dipengaruhi oleh kepuasan kerja dan komitmen organisasi. Sedangkan sisinya sebesar 14,1 persen dipengaruhi oleh variabel lain diluar model yang diteliti.

Hasil uji uji substruktur 1 dan substruktur 2 tentang pengaruh kepuasan kerja terhadap komitmen organisasi dan turnover intention di Losari Sunset Hotel Bali dapat dilihat pada tabel 4.1 sebagai berikut.

Tabel 4.1

Hasil Uji Path Analysis Pengaruh Kepuasan Kerja Terhadap Komitmen Organisasi dan Turnover Intentions Pada Losari Sunset Hotel Bali

\begin{tabular}{ccccc}
\hline No. & Hubungan Antar Variabel & $\begin{array}{c}\text { Efek } \\
\text { Langsung }\end{array}$ & Sig & Keterangan \\
\hline 1. & $\begin{array}{c}\text { Kepuasan kerja }(\mathrm{X} 1) \rightarrow \\
\text { Komitmen Organisasi }(\mathrm{Y} 1)\end{array}$ & 0,771 & 0,000 & $\mathrm{H} 1$ diterima \\
2. & $\begin{array}{c}\text { Kepuasan Kerja }(\mathrm{X} 1) \rightarrow \\
\text { Turnover Intentions }(\mathrm{Y} 1)\end{array}$ & $-0,331$ & 0,018 & $\mathrm{H} 2$ diterima \\
3. & $\begin{array}{c}\text { Komitmen Organisasi (Y1) } \\
\rightarrow \text { Turnover Intentions (Y2) }\end{array}$ & $-0,525$ & 0,000 & $\mathrm{H}$ diterima \\
\hline
\end{tabular}

Berdasarkan hasil dari uji substruktur 1 dan substruktur 2 dapat digambarkan model jalur akhir seperti gambar 4.2 berikut.

Gambar 4.2

Model Jalur Analisis

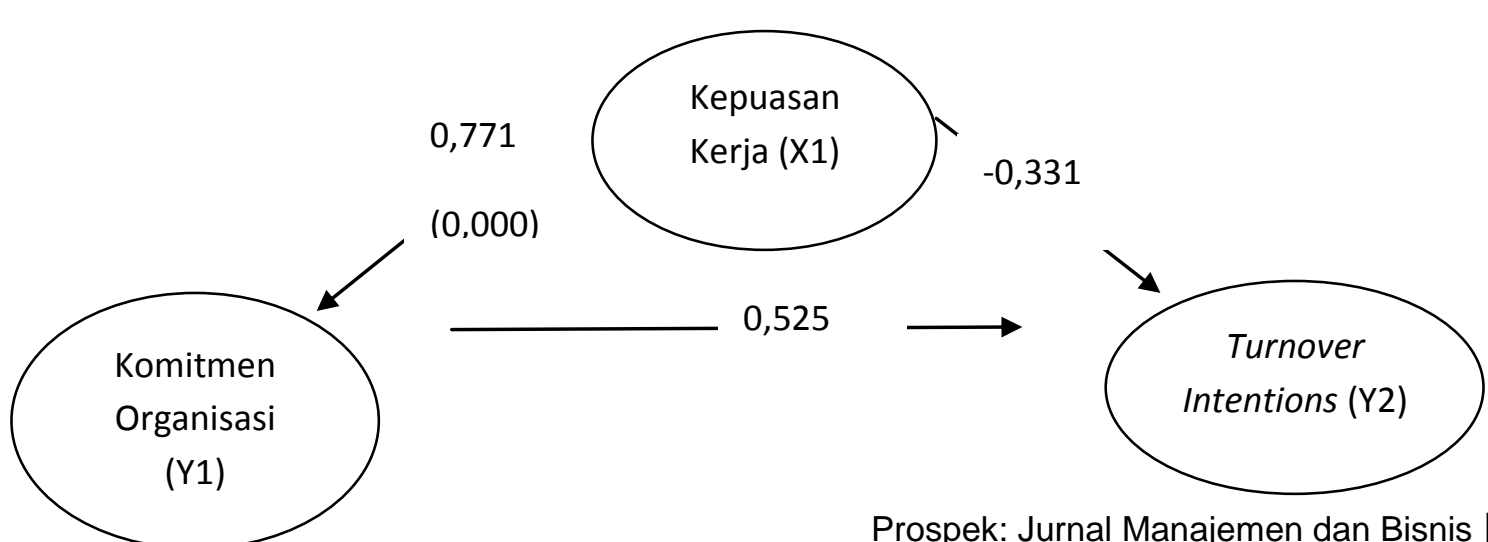

Prospek: Jurnal Manajemen dan Bisnis | 34 


\section{Pengaruh Kepuasan Kerja Terhadap Komitmen Organisasi}

Berdasarkan hasil pengujian hipotesis terlihat bahwa kepuasan kerja berpengaruh positif dan signifikan terhadap komitmen organisasi. Penelitian ini menemukan bahwa dengan kepuasan kerja karyawan yang semakin tinggi akan mampu meningkatkan komitmen organisasi karyawan di Losari Sunset Hotel Bali. Kepuasan kerja karyawan dalam penelitiannya diukur dengan lima indikator yaitu kepuasan gaji, kepuasan terhadap kesempatan promosi karir, kepuasan terhadap supervisi, kepuasan terhadap hubungan personal dan kepuasan terhadap pekerjaan itu sendiri. Berdasarkan uji diskripsi variabel menemukan bahwa kepuasan kerja karyawan Losari Sunset Hotel Bali dinilai cukup puas. Kepuasan kerja ini lebih didominasi oleh kepuasan terhadap pekerjaan yang telah dilakukan karyawan. Sedangkan indikator kepuasan gaji dinilai kurang peran dalam menunbuhkan kepuasan kerja karyawan. Dengan hasil tersebut berarti bahwa adanya peningkatan indikator kepuasan kerja akan berdampak pada peningkatan komitmen organisasi karyawan di Losari Sunset Hotel Bali. Hasil temuan ini konsisten dengan penelitian sebelumnya dari Salim (2013) menemukan bahwa kepuasan kerja berpengaruh terhadap komitmen organisasi.

\section{Pengaruh Kepuasan Kerja terhadap Turnover Intentions}

Berdasarkan hasil pengujian hipotesis terlihat bahwa kepuasan kerja berpengaruh negatif dan signifikan terhadap turnover intentions. Penelitian ini menemukan bahwa dengan kepuasan kerja karyawan yang semakin tinggi akan mampu menurunkan tingkat turnover intentions karyawan di Losari Sunset Hotel Bali. Kepuasan kerja karyawan Losari Sunset Hotel Bali yang dinilai cukup puas karena kepuasan terhadap pekerjaan karyawan sendiri berdampak pada penurunan tingkat turnover intentions karyawan. Tingkat turnover intentions karyawan lebih banyak dipengaruhi oleh adanya alternatif pekerjaan yang lebih baik dibandingkan dengan bekerja tingkat turnover intentions karyawan. Hal ini mengindikasikan bahwa, manajemen Losari Sunset Hotel Bali belum mampu memberikan kepuasan yang sesuai keinginan karyawan sehingga menimbulkan tingginya turnover intentions karyawan. Hasil temuan ini konsisten dengan penelitian sebelumnya dari Bramantara (2015) menemukan bahwa kepuasan kerja berpengaruh negatif dan signifikan terhadap turnover intentions.

\section{Pengaruh komitmen organisasi Terhadap Turnover Intention}

Berdasarkan hasil pengujian hipotesis terlihat bahwa komitmen organisasi berpengaruh negatif dan signifikan terhadap komitmen turnover intentions. Penelitian ini menemukan bahwa dengan tingginya komitmen organisasi akan mampu menurunkan turnover intentions karyawan di Losari Sunset Hotel Bali. Komitmen organsasi dalam penelitiannya diukur dengan tiga indikator yaitu komitmen afektif, komitmen kontinyu, dan komitmen normatif. Berdasarkan uji diskripsi variabel menemukan bahwa komitmen organisasi Losari Sunset Hotel Bali dinilai cukup tinggi. Komitmen organisasi lebih didominasi oleh komitemen normatif yaitu komitmen yang menekankan pada dimensi moral yang didasarkan pada perasaan wajib dan tanggung jawab karyawan pada Losari Sunset Hotel Bali. Dengan hasil tersebut berarti bahwa adanya peningkatan indikator komitmen organisasi akan berdampak pada penurunan turnover intentions di Losari Sunset Hotel Bali. Hasil temuan ini konsisten dengan penelitian sebelumnya dari Bramantara (2015) dengan judul "Pengaruh Kepuasan Kerja Dan Komitmen Organisasi Terhadap Turnover Intention (Studi pada karyawan Pada Krisna Oleh-oleh Khas Bali III)" dengan hasil bahwa diperoleh variabel komitmen organisasi mempengaruhi turnover intention. Variabel komitmen organisasi merupakan variabel yang mempunyai pengaruh dominan terhadap turnover intention karyawan Pada Krisna Oleh-oleh Khas Bali III.

\section{Simpulan dan Saran}

Berdasarkan pada hasil analisis dan pembahasan terhadap hasil-hasil penelitian sebagai output dari pengumpulan dan pengolahan data serta pengujian hipotesis sebagaimana telah diuraikan pada bab sebelumnya, maka pada penelitian ini dapat ditarik beberapa kesimpulan sebagai berikut : 
1. Kepuasan kerja berpengaruh positif terhadap komitmen organisasi. Hal ini berarti bahwa kepuasan kerja yang semakin baik mampu peningkatkan komitmen organisasi karyawan pada Losari Sunset Hotel Bali.

2. Kepuasan kerja berpengaruh negatif terhadap turnover intention. Artinya, kepuasan kerja yang semakin baik mampu menurunkan tunover intentions karyawan pada Losari Sunset Hotel Bali.

3. Komitmen organisasi berpengaruh negatif terhadap turnover intentions. Artinya, komitmen organisasi yang semakin tinggi mampu menurunkan tunover intentions karyawan pada Losari Sunset Hotel Bali.

Berdasarkan temuan hasil penelitian, diharapkan bagi manajemen untuk memperhatikan kepuasan kerja dan komitmen organisasi untuk menurunkan turnover intentions. Pihak menajemen perlu melakukan peningkatan kepuasan kerja dengan cara meningkatkan kepuasan gaji dan tunjangan sesuai dengan beban kerja. Peningkatan komitmen organisasi dapat dilakukan dengan meningkatkan komitmen afektif yang menanamkan persepsi karyawan bahwa meninggalkan perusahaan akan menimbulkan biaya dan resiko yang tinggi. Dan untuk menurunkan turnover intentions karyawan perusahaan sebaiknya meningkatkan kesejahteraan karyawan yang lebih baik dari perusahaan lainnya, sehingga kecendrungan untuk keluar dari perusahaan dapat menurun.

\section{Daftar Rujukan}

Arikunto, Suharsimi. 2002. Metodologi Penelitian. Penerbit PT. Rineka Cipta. Jakarta.

Azeem, S. Y. 2010. Job Satisfaction and Organizational Commitment among Employees in the Sultanate of Oman. Journal of Psychology, 1 : 295-299

Bramantara, Gusti Ngurah Berlin dan A.A. Sagung Kartika Dewi. 2015. Pengaruh Kepuasan Kerja Dan Komitmen Organisasi Terhadap Turnover Intention Karyawan Pada Krisna Oleh-Oleh Khas Bali III. Bali: Fakultas Ekonomi dan Basnis Universitas Udayana.

Griffin. 2004. Komitmen Organisasi. Terjemahan. Jakarta: Erlangga

Kreitner, Robert and Angelo Kinicki. 2001. Organizational Behavior. FifthEdition. Irwin McGrawHill

Koh, Hian Chye dan El'fred H.Y. Boo. 2004. Organizational Ethics and Employee Satisfaction and Commitment. Management Decision, Vol.42, No.4.Hal. 677 - 693

Luthans, Fred. 2006. Perilaku Organisasi, Alih Bahasa V.A Yuwono. Yogyakarta: Andi

Mathis, R. L., dan J.H. Jackson. 2001. Manajemen Sumber Daya Manusia. Buku 1 dan Buku 2. Terjemahan. Salemba Empat. Jakarta

Robbins, Stephen P. 2003. Perilaku Organisasi. Index. Jakarta

Salim, Agus. 2013. Pengaruh Kepuasan Kerja Terhadap Komitmen Organisasional, Kinerja, Dan Turnover Intention Pada Karyawan PT. Indospring Di Kota Gresik. E_Jurnal Wima Vol. 2 No 2 (2013). Universitas Katholik Widya Mandala Surabaya.

Setiawan, R., dan Brian, H. 2013. Pengaruh Komitmen Organisasional Terhadap Kepuasan Kerja Karyawan Paparon's Pizza City Of Tomorrow.Jurnal Studi Manajemen dan Organisasi, 1(1):21-41. 
Siregar, Ahmad Hilman. 2006. Pengaruh Kepuasan Kerja Terhadap Intensi Turnover Karyawan Produksi pada PT Riau Crumb Rubber Factory. Thesis. Universitas Sumatera Utara Medan

Sitty Yuwalliatin. 2006. Pengaruh Budaya Organisasi, Motivasi dan Komitmen Terhadap Kinerja Serta Pengaruhnya Terhadap Keunggulan Kompetitif Dosen Unissula Semarang. Jurnal Ekonomi dan Bisnis, Vol. 7 No. 2, Juli, p. 241-256.

Sutrisno, Edi. 2009. Manajemen Sumber Daya Manusia. Edisi Pertama. Jakarta: Kencana Prenada Media Group 